\title{
Charles H. Taylor
}

With the passing of Charles $\mathrm{H}$. Taylor on August 18, the Business Historical Society lost one of its founders and most effective supporters. Mr. Taylor was born in Charlestown on October 2, 1867, and he attended the Boston Latin School and Harvard College. In 1893 he became director and treasurer of the Boston Globe, which position he continued to hold until 1937. He was a forceful person whose influence not only permeated the "Globe family" and his own circle of acquaintances, but was also felt in the wide reaches of the newspaper world and in the many and varied institutions with which he was from time to time associated.

Charles H. Taylor was one of that fine element in Boston which has combined, to a degree almost unique in the experience of American cities, an interest in and appreciation of the things of the mind with a high sense of social responsibility. He won the distinction of an honorary membership in the Phi Beta Kappa chapter of William and Mary College and honorary degrees from William and Mary and from Harvard University. He was a trustee, and for many years president, of the Industrial School for Crippled and Deformed Children of Boston, a member of the Harvard Infantile Paralysis Commission, and a trustee of the Sailors Snug Harbor of Massachusetts. He was a member of the visiting committee of Harvard College on English and on history and also a member of the visiting committee of the Harvard College Library. He was a life member of the Boston Society of Natural History, which he served at various times as an officer; and a trustee of the Massachusetts State Library from 1924 to 1936. He was an active member and an officer of the Club of Odd Volumes. He was, above all, interested in history; among the many historical organizations which he supported as a member, frequently serving as an officer, may be named the American Antiquarian Society, the Virginia Historical Society, the Massa- 
chusetts Historical Society, and the Business Historical Society.

Mr. Taylor's interest in business history was of long standing but it was in the early 1920's that it became clearly focused. How far this development was a result of his earlier interest and work in history and his appreciation of the place and the problems of business in society, it is impossible to say; a very real influence, which no doubt helped to direct his historical interest into the new channel, was his contact with the Graduate School of Business Administration of Harvard University. Mr. Taylor was one of a nucleus of three or four men who were chiefly responsible for the founding of the Business Historical Society, and, since he was a man of enthusiasm with a wide circle of friends, his interest meant much to the young organization. He served the Society as president from its organization in 1925 until 1935, giving conscientious attention to a responsibility which was only one among many that were pressing on his time and energies.

He was an indefatigable collector, and because he saw meaning in history he collected its records with intelligence and insight. He looked upon the Business Historical Society as a vehicle for collecting the records of business and preserving them for the student of business history, and he contributed richly to that end. His gifts over a period of years constitute a significant contribution.

These gifts, which are chiefly original manuscript records of American business, cover a wide range in time and in businesses represented. There are a few papers from the seventeenth century, but most of the material dates from about 1750 to 1850 . It covers a space of time for which existing business records are relatively rare. Moreover, in large part it concerns a type of business man about whom little is known but who has always been important in the aggregate though insignificant as an individual, that is, the petty capitalist. Here we have the account books and other records of the house painter, carpenter, tanner, tailor, general storekeeper, farmer, whaler, lawyer, stagecoach operator, and so on. We also find in these papers the beginnings of a new stage of business development, industrial capitalisn. It is in no small measure owing to Charles $\mathrm{H}$. Taylor that the manuscript collection of business records in Baker Library, the depository of the Society, offers a rare opportunity for research in the early history of American business. 


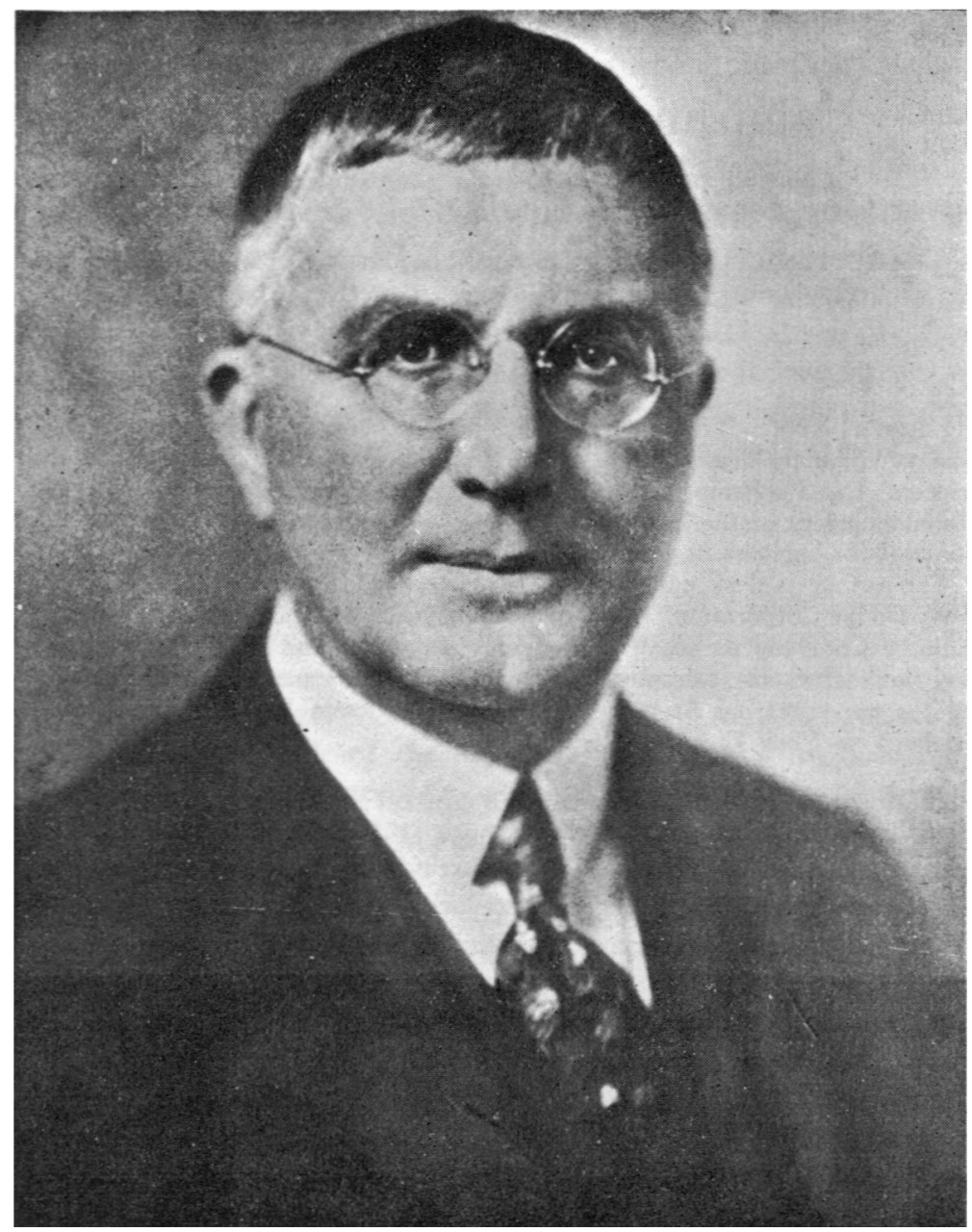

CHARLES H. TAYLOR, 1867-1941 First President of the Business Historical Society 